\title{
Bladder Urachal Carcinoma
}

National Cancer Institute

\section{Source}

National Cancer Institute. Bladder Urachal Carcinoma. NCI Thesaurus. Code C39842.

A rare variant of carcinoma of the urachal remnant of bladder. 